IJ§ER

ISSN: 2149-5939
International Journal of Social Sciences and Education Research

Online, http://dergipark.gov.tr/ijsser

Volume: 3(2), 2017

\title{
Central Bank transparency and inflation targeting: A policy performance analysis for Turkey
}

\author{
Emine Özge Yurdakurban ${ }^{1}$ Umut Öneş²
}

\begin{abstract}
Received Date: $01 / 09$ / 2016
Accepted Date: 15 / $01 / 2017$

Abstract

In the wake of recent global financial crisis, growing emphasis has been put on central bank reliability and transparency, especially for the developing countries. In our paper, we built a macroeconomic model to test the impact of central bank reliability on the inflation targeting performance by the bank. To this end, we utilized the indexes developed by Cukierman et.al.(1993); and Dinçer and Eigenberg (2013) to calculate a measure of Turkish Central Bank reliability for the past two decades, and ran a multi-equation time series regression to analyze the effect of institutional independence and transparency on inflation targeting performance, while controlling for other macroeconomic indicators that impact inflation. We found that higher degrees of perceived transparency of the central bank has a positive effect on the inflation targeting performance. Also, transparency seems to be a better proxy for the overall institutional change the Turkish economy experienced in the last two decades.
\end{abstract}

Keywords: inflation targeting, central bank transparency, central bank independence, policy performance analysis, Turkey

\section{Introduction}

Milton Friedman and Anna Schwartz famously stated that "inflation is always and everywhere a monetary phenomenon" in their now classic book titled "A Monetary History of the United States, 1867-1960" which laid most of the fault for the Great Depression on The Federal Reserve System (Friedman and Schwartz, 2008). It is of course not surprising that such a strong claim came from two most prominent advocates of monetarism; after all, at the very core of monetarism lies the age-old quantity theory of money. The modern form of the quantity theory stands on a definitional relationship that equates the total amount of money in circulation multiplied by the velocity of money to the nominal output level in a given period. The origin of this definitional relationship goes back to David Hume (1758) and John Stuart Mill (1848) and it was originally formulated algebraically by Irving Fischer (2006); the algebraic expression the relationship is known as the Fischer's equation of exchange.

While there is little or no disagreement on the validity of the equation of exchange, there has been a long tradition of disagreement on the direction of causality underlining the equation among major economists: According to Karl Marx (1970), the determinative elements of the equation are the quantity and the price of commodities; the quantity of money and velocity merely shadows them. Keynes and his followers, on the other hand, argued that the amount of money is determined by the aggregate demand in the economy; the people decide how much money to hold depending on their purchasing power. In "A Tract on Monetary Reform" (1924) Keynes derives his own

\footnotetext{
${ }^{1}$ Abant İzzet Baysal University, Bolu, TURKEY eoyurdakurban@gmail.com

${ }^{2}$ Ankara University, Ankara, TURKEY onesumut@yahoo.com
} 
Yurdakurban, E. Ö., Öneş, U. (2017). Central Bank transparency and inflation targeting: A policy performance analysis for Turkey. International Journal of Social Sciences and Education Research, 3(2), 467-474.

version of the equation and claims that a change in the amount of money in circulation will result in a change in the public's willingness to hold wealth in the form of cash or checking accounts, at least in the short run. Therefore, an increase in the total amount of money in the economy will not immediately result in a proportional increase in the price level, and potentially can affect real variables, according to Keynes.

Empirical evidence only partially support Friedman's and Schwartz's claim, and only in the long-run. Grauwe and Polan's (2005) massive study encompasses a sample of 160 countries over a period of 30 years shows the monetarist argument have a certain degree of validity in the long run, when all countries in the sample was considered. However, they also conclude that the robust linkage between inflation and money supply is "almost wholly due to the presence of high-(or hyper-) inflation countries in the sample. The relationship between inflation and money growth for low-inflation countries (on average less than $10 \%$ per annum over the last 30 years) is weak."

However, generalizing a positive correlation between money supply and inflation has its limits, even though one focuses only on the experiences of high- or hyper-inflation economies. Turkey has been a famous example for this point: Turkey's met with high CPI inflation rates (over $40 \%$ ) with the aftermath of the first oil crisis in 1977; the inflation rate rarely saw below $40 \%$ until 2002. Figure 1 shows the CPI inflation rates for the Turkish economy; as it can be seen, the 25 years between 1977 and 2002 witnessed the inflation to reach record peaks as high as $120 \%$ during major economic and/or political crises. However, even though Turkey might seem an ideal candidate for Grauwe and Polan's (2005) group of high-inflation countries given its' consistent and persistent problems with price stability, it remains an exception to the rule: Vuslat Us's (2004) analysis focuses on Turkey and he finds zero correlation between money supply (M2) and inflation for a period of 30 years; according to Us the depreciation of the Turkish Lira and high public sector prices are the culprits behind high and even-increasing inflation rate.

Us concludes his analysis by stating: "The continued success of the fight against inflation is mostly dependent on the structural programs, most of which are still to come. (....) The implementation of the structural reforms will raise credibility as the reforms are performed successfully [emphasis added]".

Figure 1. Inflation in Turkey (\%) 1990Q1-2016Q2

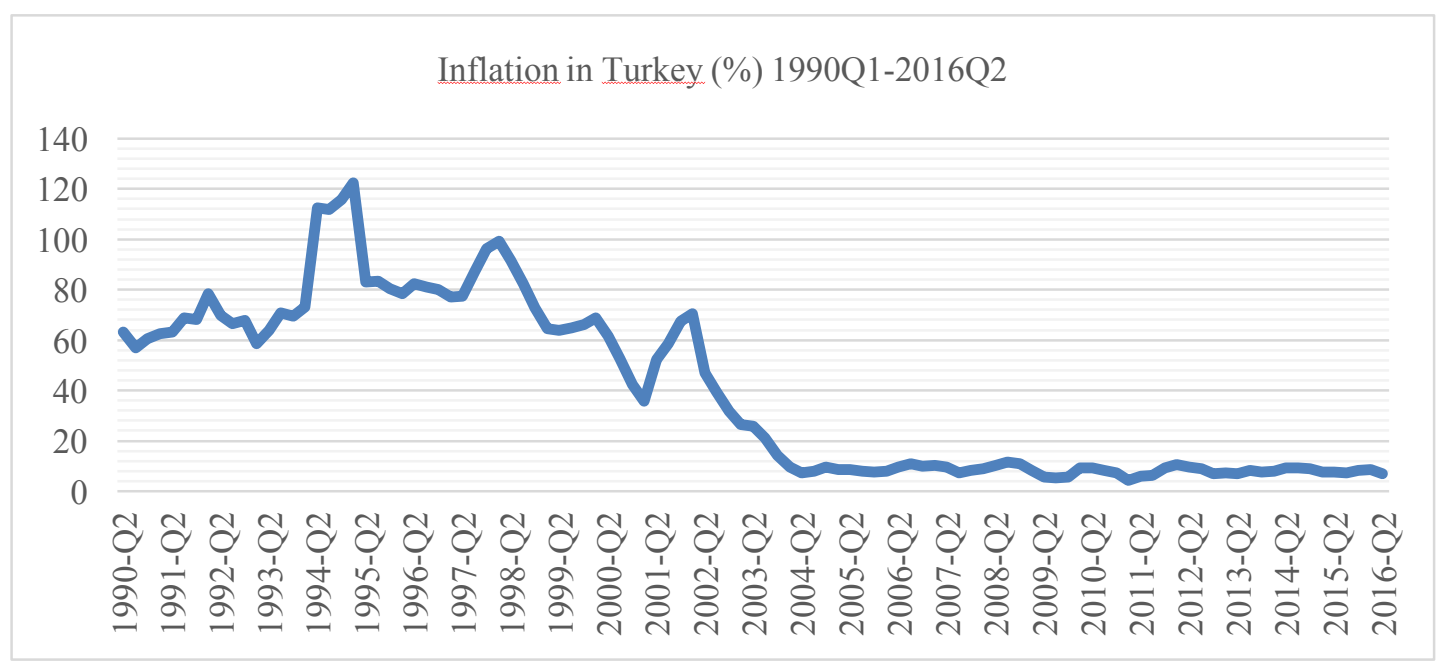


Yurdakurban, E. Ö., Öneş, U. (2017). Central Bank transparency and inflation targeting: A policy performance analysis for Turkey. International Journal of Social Sciences and Education Research, 3(2), 467-474.

In our study, we aim to show empirically how the on-going institutional changes in Turkey have affected the price stability in the country, and to what degree the economic reforms are responsible for the success story of the country after 2002 in terms of price stability. Of course, measuring institutional change objectively and properly can be tricky as it requires tested and standardized instruments. Fortunately, the recently growing literature about the institutional quality of central banks offers a solution to this problem. In Section 2, we present the two indexes (namely the transparency and independency indexes for central banks) that can be utilized as proxies for structural changes in economic institutions, while summarizing out panel data results regarding these variables in the literature. Section 3 explains the empirical model we test and the data we use to adapt the link between central bank transparency with the success of anti-inflation policies in a time-series set up. Section 5 concludes our analysis and presents suggestions for further research.

\section{Measuring institutional change: Central Bank independence and transparency}

The concept of a central bank in control of the money supply by itself indicates delegation of a certain part of economic policy responsibilities to a body outside the branches of government, and therefore a certain degree of independence from other policy authorities. An independent central bank is important for the health of the economy, given the long-time horizon of monetary policy. The political authority is likely to be tempted by short-term gains from day-to-day monetary adjustments and will be ignoring the lagging nature and the long-run costs of an expansionary monetary policy (Blinder, 1999).

Theoretical studies on how an independent agent with a set of goals and longer term than the elected politicians can lessen inflationary bias of monetary policy have increased following Rogoff's lead in 1985 (see Svensson, 1995; Bernanke et. al., 1999; and Walsh, 1995 for example). Empirical analysis on the policy performance effects of central bank independence, on the other hand, naturally necessitates a standard and universal method in order to classify various central banks with different legal structures according to their independence. One of the most utilized of such measures was offered by Cukierman et.al. (1992), as a part of the effort by Alex Cukierman and his various co-researches to examine how political forces affect economic policy. Cukierman et.al. (1992) measures the legal independence of a central bank using four main criteria: the independence of the CEO of the central bank from elected political authority, the degree of independence of the central bank in determining policy formulation, the announced objective of the central bank, and finally how rigid are the limits on lending to the public sector. Each of the main criteria have various sub-criteria with sometimes varying weights. For example, limits on lending criterion depends on the legal limits on advances to the public sector, limits on securitization of government debt, limits on the terms of loans, and the number of potential public institutions that are allowed to borrow from the central bank.

Independence of the central bank from the political authority is clearly important in developing countries given the pressure from permanent budget deficits as a result of public investments on infrastructure, populist fiscal expansions, and the loss of tax revenue due to the massive informal sectors. In 2001, following a major change in legislation, the Turkish central bank experienced a significant increase in terms of independence index according to the updated calculations by Dinçer and Eichengreen (2014). This almost 50\% increase in the central bank independence score (from 0.42 to 0.60 ) was majorly due to new limitations on the public sector lending by the bank. Although, this was certainly good news for the Turkish price stability, since the change in the 
Yurdakurban, E. Ö., Öneş, U. (2017). Central Bank transparency and inflation targeting: A policy performance analysis for Turkey. International Journal of Social Sciences and Education Research, 3(2), 467-474.

index lies outside the period we are analyzing, time series regression results fail to show any significant effect of central bank independence on the rate of inflation.

Luckily, transparency index values for Turkey show some variation during the same period, which makes it a better proxy candidate for institutional and structural change. Transparency level of a central bank simply refers to the level of disclosure about policy goals, tools and predictions with the public. The idea that transparency is a desirable quality of a central bank is quite new and can be thought of as a part of the overall trend for freedom of information and full disclosure about government policies. Banks and other financial institutions are expected to be secretive about their operations and since the central bank is a bank for national private banks as well as a last resort lender to the government; increased transparency might at first seem like a bad idea: Sharing information about loans and advances to the treasury can reveal a certain degree of incompetence of government policies and therefore may hurt the image of economic authorities in the eyes of the public. There are also bureaucratic and political reasons behind obfuscation according to Havrilesky (1987); clandestineness may serve to hide redistributive effects of monetary policy over income. Last but not the least, it is broadly accepted that in order for monetary policies to have real effects they should be unanticipated.

Despite all these arguments, heightened transparency is an ongoing trend since 1989; it all started when the Central Bank of New Zeeland started revealing interest rate forecasts and portfolio outlooks to the public. Central banks in Norway and Sweden followed suit. As of January 2012, the Federal Reserve began publishing its predictions on short-term interest rates and views on the evolution of the bank's portfolio. Furthermore, panel data results reveal that increased transparency, alongside increased independence, serves to decrease variability of inflation rates for both developed and developing countries (Crowe and Meade, 2008; Piklos, 2011; Dinçer and Eichengreen, 2014).

For our time series analysis on Turkey, we use the updated version of transparency index provided by Dinçer and Eichengreen (2014). Their calculations depend on five main criteria of transparency: political transparency which refers to the openness about policy goals, economic transparency in relation to the economic data that is used to design the monetary policy, procedural transparency that concern the decision making method of the bank, policy transparency which relates to the time frame in which the policy decisions are shared with the public together with the explanations for the decision, and finally operational transparency which regards the execution of policy actions as well as the evaluation of outcomes.

Turkish transparency index has been on the rise beginning with the year 2000: an increase is observed in 2001, following the implementation of "the pegged within the bands" exchange rate targeting with disastrous results; another one in 2002 right after the financial crisis and new structural adjustment policies that followed; another increase in 2004 subsequent to the announcement regarding plans for explicit inflation targeting "when conditions are deemed appropriate", and finally in 2006 with the full adaptation of explicit inflation target as the primary policy tool. The fact that all the major shifts in the transparency level of the Turkish central bank coincides with major structural changes in the overall economic policy can be interpreted as a sign that transparency index may be a better proxy for institutional transformation of the economic policy establishment in Turkey (Erçel, 1999; Özatay, 2009). 
Yurdakurban, E. Ö., Öneş, U. (2017). Central Bank transparency and inflation targeting: A policy performance analysis for Turkey. International Journal of Social Sciences and Education Research, 3(2), 467-474.

\section{Models and results}

Our main concern is how the institutional structure of the Central Bank of the Republic of Turkey (CBRT) have impacted the price stability performance of the monetary policy. Of course, in order to measure policy performance one needs clearly defined policy goals. Even though the CBRT began using inflation targeting as the primary policy goal after January 2002, for the following four years the targeted level of inflation was not explicitly announced to the public. January 2006 marks the initial announcement of the target level of inflation, and the bank continued to update the target in the beginning of each year that follows. However ex-post data for the (unannounced) inflation targets are available beginning with 2004. Therefore, the data set for performance analysis is limited to observations between 2004 and 2016 only. As mentioned above, the independence index does not display any change in the period in question, leaving only the transparency index as a viable qualitative measure for the institutional change in the central bank during the inflation targeting era. However, international data reflects that independence and transparency generally move together in the same direction since they usually change as a result of the same structural reforms (see Bernanke, 2010 for an overview), so that they may be interpreted as closely correlated variables.

Therefore, our inflation targeting policy performance model includes solely the transparency index as the control for institutional change, along with that usual independent variables used in inflation rate models:

\section{Rate of Change in derivation from the inflation target $=\beta_{0}+$$$
\beta_{1} \Delta\left(\pi_{t-1}^{a}\right)+\beta_{2} \Delta\left(Y_{t}\right)+\beta_{3} \Delta\left(M 2_{t}\right)+\beta_{4} \Delta\left(E E X_{t}\right)+\beta_{5}\left(\text { TRANS }_{t}\right)+
$$$$
\beta_{6} \text { Dummy }_{t}+u_{t}
$$

Our dependent variable is rate of change in the deviation of the realized inflation rate $\left(\pi_{t}^{\mathrm{a}}\right)$ from the targeted inflation rate $\left(\pi_{t}^{\mathrm{tay}}{ }^{\mathrm{et}}\right)$. We control for the effects of change in the preceding inflation rate with the lagged $\Delta \pi_{t-1}^{2}$ variable to correct for autocorrelation. The remaining independent variables are the growth rate of real GDP $\left(\Delta Y_{t}\right)$, the rate of change in the M2 money supply $\left(\triangle M 2_{t}\right)$, rate of change in the real effective exchange rate $\left(\triangle E E X_{\mathrm{t}}\right)$, and finally the transparency index.

Figure 2. Turkish Real GDP Growth Rate (Quarterly 2004Q1-2016Q2)

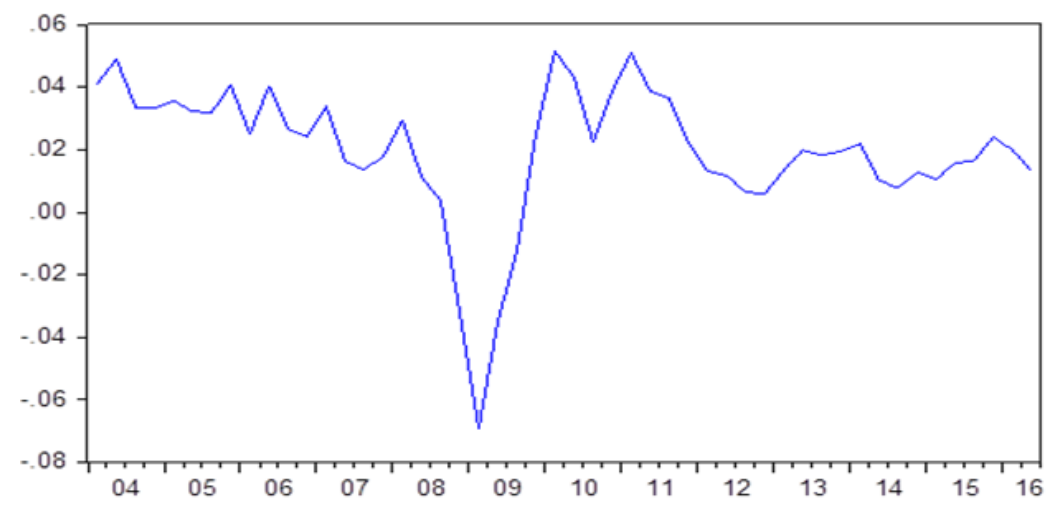

Source Data: Central Bank of the Republic of Turkey, http://evds.tcmb.gov.tr/ (accessed December 2016) 
Yurdakurban, E. Ö., Öneş, U. (2017). Central Bank transparency and inflation targeting: A policy performance analysis for Turkey. International Journal of Social Sciences and Education Research, 3(2), 467-474.

We also use a dummy variable for the observations between the third quarter of 2008 and the third quarter of 2009, in order to control for the impact of the financial crisis on the real GDP as well as other factors. The significant drop in the reel GDP growth rate in this period is shown in Figure 2 above.

Our observation range is between the first quarter of 2004 and the second quarter of 2016 (naturally we lose one observation in the beginning due to the lagged inflation variable). We extent the transparency index reported by Dinçer and Eichengreen (2014) to 2016 as unchanged, since there has been no legislature change in the bylaws of CBRT after 2006. Our results are presented in Table 1 below.

Table 1. Change in derivation from the inflation target

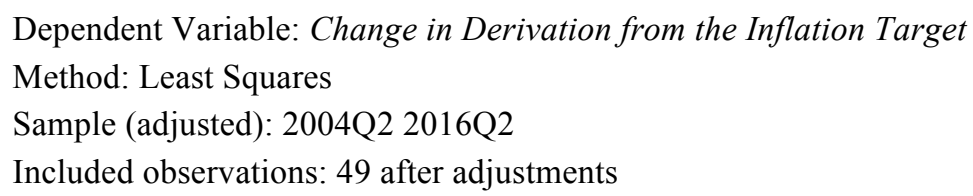

\begin{tabular}{lllll}
\hline \hline Variable & Coefficient & Std. Error & t-Statistic & Prob. \\
& & & & \\
\hline \hline & & & & \\
Constant & 0.078614 & 0.145848 & 0.539015 & 0.5927 \\
$\Delta \pi_{r-1}$, & 5.752824 & 1.538741 & 3.738658 & 0.0006 \\
$\Delta Y_{i}$ & 2.364299 & 0.604749 & 3.909557 & 0.0003 \\
$\Delta M 2$, & 0.353606 & 0.133001 & 2.658672 & 0.0111 \\
$\Delta E E X$, & -0.207684 & 0.213256 & -0.973873 & 0.3357 \\
DUMMY & -0.133700 & 0.028002 & -4.774684 & 0.0000 \\
TRANSPARENCY & -0.023667 & 0.010878 & -2.175662 & 0.0353 \\
& & & & \\
\hline \hline & & & & 29.63969 \\
R-squared & 0.808950 & F-statistic & & \\
\hline \hline
\end{tabular}

Coefficient for transparency index is significant at 5\% confidence interval and negative as anticipated: heightened transparency leads to more accurate inflation targeting. This is in accordance with the multi-country panel data results. Coefficients for real GDP growth rate, nominal money supply growth rate, and the lagged inflation rate of change are all significant for at least within 5\% confidence interval, signs of these coefficients are also in agreement with the theory. Even though the negative coefficient for rate of change in real effective exchange rate also fits the general literature, it is not significant.

\section{Conclusion}

A monetary policy aiming at a long-term price stability needs concurrency of decisions, given the long-horizon and lagged nature of the impact of the money supply changes. Heightened independence enables a central bank to choose policy goals and tools freely, away from the influence of the elected political officials' short-term desires and populist temptations. It also limits the governments usage of the bank as a last resort for funding. Increased transparency or openness 
Yurdakurban, E. Ö., Öneş, U. (2017). Central Bank transparency and inflation targeting: A policy performance analysis for Turkey. International Journal of Social Sciences and Education Research, 3(2), 467-474.

about the inner workings of the central bank, on the other hand, ensures the economic decision makers that these policies is will carry a certain degree of consistency in the long run. Therefore, steps towards heightened transparency and independence of a central bank in the form of legislative changes are likely to increase the effectiveness of policies towards price stability.

The Turkish economy had been infamously struggling with high inflation rates and all the ambiguity and reliability issues they cause during 1980's and 1990's. Structural reforms, which were in part shaped by stand-by agreements with the International Monetary Fund, gained pace especially in the wake of the 2001 financial/political crisis. Finally, after the adaptation of inflation targeting method as the primary monetary policy tool, Turkey seems to be able to attain some degree of price stability, which is vital for a developing country that faces ever increasing current account deficits and the finance sector risk they bring.

Our empirical model indicates that in Turkey between 2004 and 2016, increases in the transparency index have influenced inflation targeting policy positively; when the impact of real income, money supply, past inflation, and the effective real exchange rate are controlled for in a time series regression. This result is consistent with the multi-country cross-section data studies in the literature.

\section{References}

Bernanke, B. S. (2010, May). Central bank independence, transparency, and accountability. In Institute for Monetary and Economic Studies International Conference, Bank of Japan, Tokyo (Vol. 25).

Bernanke, B. S., Laubach, T., Mishkin, F. S., \& Posen, A. S. (1999). Inflation targeting. Princenton University Press.

Blinder, A. S. (1999). Central banking in theory and practice. Cambridge, MA, MIT Press.

Crowe, C., \& Meade, E. E. (2008). Central bank independence and transparency: Evolution and effectiveness. European Journal of Political Economy, 24(4), 763-777.

Cukierman, A., Webb, S. B., \& Neyapti, B. (1992). Measuring the Independence of Central Banks and Its Effect on Policy Outcomes. The World Bank Economic Review, 353-398.

Dincer, N. N. and Eichengreen, B. (2014). "Central Bank Transparency and Independence: Updates and New Measures." International Journal of Central Banking 10, no. 1, 189-259.

Erçel, G. (1999). Disinflation program for the year 2000: Implementation of exchange rate and monetary policy. TCMB.

Fisher, I. (2006). Purchasing power of money: Its determination and relation to credit interest and crises, Cosimo, Inc.

Friedman, M., \& Schwartz, A. J. (2008). A monetary history of the United States, 1867-1960. Princeton University Press.

Grauwe, P. D., \& Polan, M. (2005). Is inflation always and everywhere a monetary phenomenon? The Scandinavian Journal of Economics, 107(2), 239-259.

Havrilesky, T. M. (1987). A partisanship theory of fiscal and monetary regimes. Journal of Money, Credit and Banking, 19(3), 308-325.

Hume, D. (1907). Essays: Moral and Political and Literary (Vol. 1.) Longmans, Green, and Company.

Keynes, J. M. (1924). A tract on monetary reform. Macmillan and Company Limited. pp.80-84.

Marx, K. (1970). A contribution to the critique of political economy $\sigma^{\text {th }}$ Ed. Moscow: Progress Publishers.

Mill, J. S. (1848). Principles of Political Economy With Some of Their Applications to Social Philosophy. 1857. George Routledge and Sons, Manchester. 
Yurdakurban, E. Ö., Öneş, U. (2017). Central Bank transparency and inflation targeting: A policy performance analysis for Turkey. International Journal of Social Sciences and Education Research, 3(2), 467-474.

Özatay, F. (2009). Türkiye’de 2000-2008 döneminde para politikası. Iktisat Isletme ve Finans, 24(275), 3765.

Rogoff, K. (1985). The Optimal Degree of Commitment to an Intermediate Monetary Target. The Quarterly Journal of Economics, 100(4), 1169-1189.

Siklos, P. L. (2011). Central bank transparency: another look. Applied Economics Letters, 18(10), 929-933.

Svensson, L. E. (1995). Optimal inflation targets, conservative central banks, and linear inflation contracts (No. w5251). National Bureau of Economic Research.

Us, V. (2004). Inflation dynamics and monetary policy strategy: some prospects for the Turkish economy. Journal of Policy Modeling, 26(8), 1003-1013.

Walsh, C. E. (1995). Optimal contracts for central bankers. The American Economic Review, 85(1), 150167. 